\title{
A Worthy Reception? Ambivalences in Social Work With Refugees and Migrants in Sweden
}

\author{
Kristina Gustafsson \\ Jesper Johansson
}

\begin{abstract}
The purpose of this article is to analyze how reception practices and the meaning of a "worthy" reception of refugees and migrants are negotiated in encounters between various receiving actors in times of shifting Swedish migration policies. The analysis is grounded in ethnographic methodology and draws on data collected in 2016. The aim of the study was to document experiences of the so-called "refugee crisis" in Europe and Scandinavia from a bottom-up perspective among professionals and volunteers narrated during reference group meetings. The reference groups consisted of representatives from state and municipal agencies, the private sector, and civil society organizations. The actors represented in the mixed reference groups were diverse, but all were involved in reception activities. In the analysis we have combined political philosophy about willingness versus ability to receive refugees and migrants with postcolonial theoretical perspectives on concurrent claims and voices. We identified three themes that are central in the negotiation of the practice and meaning of a "worthy reception": first, the overlooked existential needs of refugees and migrants; second, the lack of gender- and diversity-sensitive reception practices; and third, ambivalences in relation to various refugees groups in times of shifting migration policies. We recommend that in order to promote a worthy reception of refugees and migrants, existential needs must be taken care of and gender-and diversity-sensitive practices must be developed. Another recommendation is to recognize how migration policy limits a society's ability to receive refugees and migrants, but also affects the willingness among those actors who receive.
\end{abstract}

Keywords: Migrants; refugees; reception; social work

Today, migration policies in liberal democracies are marked by an ambivalence between seemingly contradictory jurisdictions and claims (Andersson, 2014; Gibney, 2004). This ambivalence can be seen in the public debate, with themes such as human rights versus national security and the rights of refugees versus the right to protect national welfare state institutions. In Sweden, such contradictions manifested themselves with the implementation of a new law in 2016 which restricted the possibilities for permanent residency and family reunion for asylum seekers (SFS 2016:752). Political leaders justified the law by referring to the pressure that an increased influx of refugees in 2015 put on migration agencies, social services, schools, health and medical care and so on. The "refugee crisis" of 2015 was thus framed as a crisis for the receiving country rather than a crisis for the people seeking protection (SOU 2017:12).

Thus, the "refugee crisis" was framed and re-framed in similar ways in several European countries. In some countries, like Sweden and Germany, the rhetorical reactions of leading politicians in 2014 and 2015 concerning the increased numbers of arriving asylum seekers were marked by solidarity and empathy. In a speech in the summer of 2014, then Swedish Prime Minister Fredrik Reinfeldt, who lead a center-

Kristina Gustafsson, PhD, is an Associate Professor, Department of Social Work, Linnaeus University, 35195 Växjö, Sweden. Jesper Johansson, PhD, is an Assistant Professor, Department of Social Work, Linnaeus University, 35195 Växjö, Sweden. 
right coalition government, exhorted the Swedish people to "open your hearts" towards asylum seekers fleeing war-torn regions. Furthermore, conservative German Chancellor Angela Merkel commented on the increased numbers of received asylum seekers in Germany in autumn 2015 with the words "wir schaffen das" "We will make it"), addressing a symbolic message to the German people to have trust in the German society's ability and willingness to receive refugees. In contrast, other countries like Poland, Hungary and Slovakia consistently turned away asylum seekers and refugees. Nevertheless, even in countries like Sweden and Germany, the political atmosphere concerning migration policies changed radically during late autumn 2015 and the following years. New regulations and strict border controls were implemented not only around the external borders of the EU but also (temporarily) between EU countries to limit migration movements. One of the main arguments for these increasingly strict measures in European countries was the fact that there was, and still is in 2018, a split among EU countries. Several Eastern and Central European countries did not want to receive asylum seekers and refugees at all. Others, mainly South European countries close to the Mediterranean Sea where large numbers of migrants first arrived, as well as Germany and Sweden as the largest receiving countries, preferred to establish a redistribution system leading to an obligation of all EU-countries to receive a "fair" share of asylum seekers and refugees migrating to the EU (Gibney, 2015; Regeringens skrivelse, 2016; Svensson, 2017, pp. 20-21).

In Sweden the new law about restrictions on permanent residency and family reunification can be described as a turning point in Swedish migration policy (Johansson, 2005), which has had a significant impact on everyday social work connected to the reception of refugees and migrants. On the one hand, professionals and volunteers have been obliged to act in accordance with the new restrictive legislation. On the other hand, they are endeavoring to provide a welcoming and "worthy" reception in line with professional ethics and the ambitions of a social democratic welfare regime (Esping-Andersen, 1990; International Federation of Social Workers [IFSW], 2012/2004). In this way, the reception of refugees and migrants is practiced and produced on the front line between divergent but concurrent demands in contemporary Sweden. The purpose of this article is to analyze how reception practices and the meaning of a "worthy" reception of refugees and migrants are negotiated in encounters between various receiving actors in times of shifting Swedish migration policies. Our primary research question is: How is the meaning of a "worthy" reception negotiated in personal narratives by different professionals and volunteers?

The study is based on data collected in the fall of 2016 from eight recorded reference group meetings with three mixed groups consisting of both professionals and volunteers involved in the reception of migrants and refugees. In our analysis, we combine political theory about a society's ability and/or the willingness to receive refugees and migrants with postcolonial perspectives on concurrences in cultural encounters.

\section{Research Perspectives on Swedish Refugee and Migrant Reception}

This study intersects research in social work, migration studies, and cultural sciences. We employed a broad definition of social work, which includes professionals and civil society volunteers involved in the asylum process and the reception of asylum seekers. Social work has a given function in civil society organizations. Civil society involves individual commitment, which has been clarified in reception activities of 
refugees and migrants during the last several years. For instance, civil society volunteers organize a variety of relief efforts, such as serving food, collecting and distributing clothes and arranging temporary housing for refugees and migrants. In Sweden, civil society organizations have sometimes taken the place of state or municipal authorities in providing social services for refugees and migrants when these public actors have failed or ceased to act. Furthermore, professional social workers in public organizations have also cooperated with civil society organizations, sometimes using civil society as an arena to support the public authorities' efforts (Turunen \& Weinryb, 2017).

In Scandinavia several studies have been conducted on workers at the Swedish Migration Agency (Brekke, 2004; Hedlund, 2016; Ottosson \& Lundberg, 2013; Valenta \& Berg, 2010), those who work with newly arrived children in the Swedish school system (Bunar, 2015; Nilsson Folke, 2017), in social services (Montesino \& Righard, 2015), within health care services (Safipour, Hadziabdic, Hultsjö, \& Bachrach-Lindström, 2017) and at the Swedish Public Employment Agency or the National Social Security Agency (Schierenbeck, 2003; Soydan, 1995). A great deal of previous research has focused on how Swedish receiving sectors deal with integration and issues of promoting resilience, health and identity, as well as how they are marked by racism and structural discrimination (Andersson, Ascher, Björnberg, \& Eastmond, 2010; Eliassi, 2015). Although these studies are relevant for the present study, they all focus on the reception measures of one specific welfare sector or authority separately. In order to understand the reception of refugees and migrants as the sum total of many different agents and institutions in the welfare state, a comprehensive and inclusive perspective on reception is necessary (Gustafsson, 2015).

Within the field of migration research there is a growing critique of the tendency to focus on the migrants' backgrounds and experiences rather than the contexts, structures, and actors forming the conditions of migration. In the field of social work, "cultural differences" or "otherness" is often framed as the "problem" explaining migrants' weak structural integration. Migrants' "otherness" is often targeted in specific interventions (Ahmadi, 1998/2003; Hessle, 1988). Such social interventions are often focused on migrants' ability and willingness to adapt to Swedish society instead of the surrounding advantageous or disadvantageous conditions that exist concerning migrant's integration Montesino \& Righard, 2015, pp. 11-12). One consequence of such a perspective is that the migrant becomes the "problem," or the one who needs to change in order to integrate. This is known as the "minority model" (Pripp, 2005).

This critique is also present among scholars influenced by postcolonial theories that suggest a shift in focus to the surrounding society in order to understand the conditions for migrants and migration (Andersson, 2014). This suggestion is supported by several studies within the fields of migration studies and social work or social policy that show that the character of social policy and immigration policy regimes strongly influences refugees' and migrants' level of control over their own empowerment, participation, and well-being (Castles \& Miller, 2011; Montesino \& Righard, 2015; Sainsbury, 2012). In contrast, however, other studies show that reception measures take their point of departure from the needs of the host society, rather than the needs of the migrant. This leads to an ambivalent position of the migrant who is offered reception measures that might be empowering. At the same time, it is not measures that the migrant can choose or suggest themselves. In that sense, the migrant has relatively less 
power (Andersson, 2014; Gibney, 2015; Gustafsson, Fioretos, \& Norström, 2012; Larsen, 2011). These concerns are central to the perspectives of the present study. The surrounding society, here primarily represented by different welfare state professionals and civil society volunteers, and its reception measures are regarded as central for understanding the challenges of migration and the resettlement of migrants (Castles \& Miller, 2011; Johansson, 2008).

\section{Theory and Concepts}

Zetterqvist Nelson and Hagström (2016) use the concept of "reception structure" to characterize the Swedish reception of refugees and migrants. According to Zetterqvist Nelson and Hagström (2016), the concept clarifies how Swedish reception involves different sectors and agencies, each of them governed by their own laws and regulations (pp. 11-12). These sectors and agencies operate largely independently of each other rather than in close collaboration. Accordingly, Sweden's reception of refugees and migrants is not a "system" governed by one general law or regulation, but a complex "reception structure" consisting of different sectors and agencies such as the Police, the Migration Agency, municipal institutions such as schools and social services, regional health care, civil society, and private companies. The private sector is part of the reception structure since parts of the public welfare include contracted services from the private sector. Residential care homes for unaccompanied children and accommodations for asylum seeker families are often run by private companies (Zetterqvist Nelson \& Hagström, 2016, p. 12).

The concept of "reception" refers to a broad and complex arena of actions surrounding refugees and migrants (Andersson, 2014). As a consequence, many of the actors included are not specialized in reception in the administrative or legal sense, but work as teachers in schools, public officials or social workers and encounter refugees and migrants in their everyday work as a consequence of migration. They all have an impact on the refugees' and migrants' lives, but how they operate and intersect, as well as the joint outcome of their work, is difficult to understand if their agency and professional practices are not analyzed together (Andersson, 2014; Gustafsson, 2015; Zetterqvist Nelson \& Hagström, 2016).

Encounters taking place in the reception of refugees and migrants are theoretically framed by the concept of "cultural encounters." This concept is contested, first and foremost, in how it has been used by researchers to describe and evaluate differences between people based on ethnicity and nationality, often in hierarchal, stereotypical and oppressive ways (Hall, 1997; Hastrup, 2010). In present postcolonial research, however, the concept is still used both to understand encounters between colonizers and colonized peoples and to investigate how different knowledge-producing groups give voice to concurrent perspectives and interpretations of the world (Brydon, Forsgren, \& Fur, 2017). The concept of “concurrences” refers to simultaneous but contradictory process of meaning-making for example, agreement, competition, entanglement and incompatibility (Fur, 2017, p. 45). Used in research on colonial asymmetries, indigenous people or, as in this case, migration, the concept of concurrences opens up for a respect for pluralism and entanglements rather than singling out dominant perspectives and separate claims and jurisdictions. Fur (2017) notes, "It is not a multiplicity of histories per se that interests me, but the way in which they become entangled, ensnared by their competing jurisdictions" (p. 51). A challenge for researchers is to acknowledge and handle such a plurality of knowledge regimes 
and how they are concurrent but also given disparate authority and power to dominate and silence each other (Fur, 2017, p. 42).

Departing from this perspective, we consider the cultural encounter as a fruitful description of the encounters of those involved in the reception. The actors involved work for state and municipal agencies, private enterprises, and civil society organizations. They operate in organizations that have different jurisdictions and mandates depending on their assignment. For example, a social worker or a teacher working at the municipal level is involved in reception work but on different terms than an actor working at the state level for the Swedish Migration Agency or for a civil society organization. We consider the actors involved in reception work as representing different knowledge-producing groups. They work as professionals and volunteers under different jurisdictions and give voice to different claims that sometimes exist in parallel to each other and at other times converge. Taken together, they are involved in processes of negotiation that produce the meaning of a worthy reception.

In this study, political philosophy theories about the reception of refugees and justice between states are used in order to analyze the notion of worthiness. These theories are explored and advanced by political scientist Gibney (2004, 2015), who writes about the obligation of liberal democracies to receive refugees and offer resettlement. Gibney investigates the need for justice and standards for an equitable division between states of the responsibilities for refugees. In connection to a fair distribution based on statistical data, population, GDP etc., Gibney (2015) also discusses the relation between the ability and the willingness of a state to receive refugees. He suggests that the ability of a state to accept refugees might be influenced by the level of racism amongst the populace, its previous experience of integrating noncitizens and community preferences for particular types of refugees. He concludes that such factors say more about the willingness of a state to take refugees than its actual ability to do so (Gibney, 2015, pp. 456-457).

We use the terms ability and willingness in the analysis of a worthy reception. Ability frames the way participants in the reference groups identify and explain their assignment to receive refugees and migrants. Their assignment is controlled by legislation and limited by their mandate, resources and competence. In these ways, the ability to receive is in certain respects restricted. To fulfill reception work within these limits could be considered as a minimum for a worthy reception. As Gibney (2015) states, the willingness to receive refugees and migrants is restricted by more subjective considerations and non-measurable factors. In a qualitative study such as this one, subjective perspectives and meanings were what we are actually looking for. Although ability and willingness are difficult to quantify, they still have a significant impact on reception. A society's willingness to receive refugees and migrants can be stronger or weaker than its ability to do so. For example, in contemporary Sweden, more and more professionals in social services engage in volunteer work with refugees and migrants in their spare time in order to be able to do everything they want to do, not only what they can do within the framework of their professional work.

\section{Methods}

This study is part of a regional project in southern Sweden which documented professional and volunteer experiences from the reception of refugees and migrants in 2015 and 2016. The project was conducted in 2016 as a collaboration between four 
scholars in social work and cultural sciences, two curators at regional museums, and two regional public officials. The documentation of professional and volunteer experiences and voices was implemented using reference groups and individual interviews. We divided 15 selected professionals and volunteers into three reference groups who met for three sessions of three hours each during the fall of 2016. The participants represented state agencies: the Public Employment Agency, the Migration Agency and the Police; municipal agencies: social services, schools and group residences for unaccompanied minors; private entrepreneurs running refugee accommodations and civil society organizations: the Red Cross, the Church of Sweden and Fryshuset (the Freezer House). Following the last meeting, eight participants were interviewed individually by students at the university.

Through our method of gathering these representatives in mixed groups, we included different perspectives from various knowledge-producing groups in an open dialogue with each other. In the dialogue, they describe their experiences in narratives, explore their own claims and jurisdictions, and compare and negotiate with the others. Participants explored how their perspectives and functions in the reception of refugees and migrants are entangled and concurrent. Each meeting with the three reference groups was recorded. In total, the data consists of 16 hours of recorded narratives and discussions from reference group meetings and eight individual interviews. In all three groups, the group leaders (the researchers) endeavored to give space for all participants to present themselves, their organization, and their experiences and perspectives on the reception of migrants and refugees from the fall of 2015 to the fall of 2016.

The analytical work of coding and finding central themes in the data started during the period of data collection. After the first meeting with the three reference groups, central themes in the data that could be discussed at the second meeting were isolated. Four themes came forward in the coding of the first meetings: the elusive concept of integration, the overlooked existential needs of refugees and migrants in reception work, the problem of non-gender-sensitive reception, and the problem of a reception that makes the received refugees and migrants passive. These themes were further discussed in the second and third meetings. After finishing the data collection, we repeated the coding of the data and in this process three main themes emerged. Two themes overlapped with those discussed at the second and third meetings: the overlooked existential needs of refugees and migrants in the reception work (particularly the existential vulnerability and uncertainty of asylum seekers, the lack of meaningful everyday activities and existential life beliefs) and gender- and diversityinsensitive practices. A third theme was not discussed in the reference groups, nor in the individual interviews, but seems fundamental in the negotiation of a worthy reception, namely, ambivalences towards different groups of refugees and migrants in times of shifting migration policies.

\section{The Swedish Reception of Refugees and Migrants}

According to current legislation, the Swedish Migration Agency has the general responsibility not only for the asylum procedure but also for the reception of asylum seekers (SFS 1994:137). The latter is organized in collaboration with regional and municipal authorities. For unaccompanied children the legislation is different, and according to the Social Service Act (SFS 2001:453), municipalities have the responsibility for reception measures while the Migration Agency is responsible for administering the asylum procedure (Gustafsson, 2015). 
After asylum seekers receive a residence permit, they also get a specific municipality placement and the responsibility concerning refugees' and migrants' resettlement is divided between different state and municipal agencies. Municipalities are responsible for housing (SFS 2016:38). According to a 2010 law about resettlement activities (SFS 2010:197), refugees and asylum seekers with a residence permit are entitled to a resettlement plan formed in consultation with the concerned individual and managed by the Public Employment Agency in collaboration with municipalities, authorities, companies, and civil society organizations. Before 2010, this was a municipal responsibility. However, municipalities are still responsible for providing Swedish-language training and social information about laws, regulations, and civic instructions. The National Social Security Agency is responsible for paying a resettlement benefit to the refugee or asylum seeker when he or she has been given a resettlement plan by the Public Employment Agency. Looking back on the Swedish Migration Agency's statistics, family reunification was the most common reason for migration to Sweden. Besides asylum-seeking and family reunification, Sweden has granted quota refugees permits registered by the UNHCR since the 1950s. Other bases for obtaining a residence permit include work or study in Sweden. Citizens of the European Union/European Economic Area EU/EEA-member countries are also eligible to relocate to Sweden and receive a residence permit (Migrationsverket, 2017).

In 2013 and 2014, Sweden experienced a major increase in the influx of refugees and migrants when around 54,000 people in 2013 and over 81,000 people in 2014 applied for asylum. However, in the fall of 2015, most municipalities were still quite unprepared for the more than 160,000 asylum seekers that entered Sweden within the space of a few months (Migrationsverket, 2017). In relation to Sweden's total population of around 10 million people, these were remarkable immigration figures.

The reception of people seeking asylum has also been an international and European matter of concern during the last decades (Europeiska Unionen, 2010). The European Union's directive of asylum reception from 2013 aimed to harmonize policies between member states and set up minimum standards about asylum reception. The directive states that the reception should be conducted with respect for human dignity (§35), but that the member states nonetheless have the right to treat asylum seekers less favourably than their own citizens (\$24) (Europeiska Unionen, 2013). These contradictory objectives have created tensions and triggered conflicts between member states in the European Union, where some states have received large numbers of asylum seekers while other states have received very few. Furthermore, these contradictory objectives give nation states latitude to radically alter the terms and conditions of reception at short notice, for example, by reducing the standards of accommodation, language training, social activities, and other services offered to refugees and migrants.

As noted in the introduction, Sweden went through a shift in migration policy in 2016. Restrictive border controls in November 2015 and personal ID controls on trains, ferries, and buses were implemented in January 2016 followed by temporary changes in the migration law in July 2016. These changes in law and practice were implemented in order to restrict the increased influx of asylum seekers. Before July 2016, successful asylum seekers were offered permanent residence permits. Since the implementation of the new law, asylum seekers can only receive temporary residence permits from 13 months up to three years. Since July 2016, only those with refugee status according to the UN Refugee Convention have the right to family reunion (SFS 2016:752). Before 
the new law was implemented family reunion was a fundamental social right for an immigrated person with a residence permit, regardless if the person was given a residence permit based on refugee status, subsidiary protection or labor market reasons. With increased legal restrictions, Sweden downsized its reception of asylum seekers to a minimum standard compared to European Union standards (Regeringens skrivelse, 2016). Due to changes in the law and agreements made between Turkey and the EU, the influx of asylum seekers has decreased in recent years. In 2016, Sweden received less than 29,000 applicants. Asylum seekers in the last few years have come from Syria, Afghanistan, Iraq, Somalia, Iran and Eritrea or were stateless. War and conflicts are the main reason for leaving these countries of origin. In 2016, 111,979 persons received a decision and 69,682 received a residence permit (77\%), but only 17,000 were recognized as refugees. The rest were regarded eligible for subsidiary protection (Migrationsverket, 2017).

\section{Results}

\section{Overlooked Existential Needs}

The first central theme identified during the coding process of the interview data was that refugees' and migrants' existential needs were partly overlooked during their reception. We have structured the findings around this theme following three different perspectives discussed in the reference group meetings: the existential vulnerability and uncertainty of asylum seekers, the lack of meaningful everyday activities, and existential life beliefs.

One case worker at the Migration Agency told a story about her personal experiences of working in an asylum unit, where she encountered asylum seekers who felt frustrated about their situation and the long waiting time of more than one year for asylum applications. She described the atmosphere in the waiting hall of the asylum unit as characterized by despair and agony. The case worker's story was followed by a discussion about the poor situation of asylum seekers waiting for a decision. The process takes time and it is well-documented in research that such a waiting period can completely break down applicants' self-confidence and hope (Brekke, 2004; Valenta \& Berg, 2010). The main problem is of course the time; it takes too long to receive a decision. But another problem is that the asylum seekers often become extremely passivized. Language training, workforce trainee programs, and other kinds of activities are not always offered or permitted before applicants have received a decision.

Actually, the right to education for children is the only welfare service that is offered that constitutes a "normal" everyday life situation for those awaiting a decision (Svensson, 2013). For adults there is no similar occupation offered although these circumstances have gradually changed since we did the reference-group interviews with professionals and volunteers in autumn 2016. From January 2017, the County Administrative Boards in Sweden are in charge of coordinating and funding early interventions for asylum seekers or persons with residence permits living in the Migration Agency's accommodations and waiting to be allocated a municipality placement. These early interventions aims to hasten the resettlement process and help to make the waiting time, when the asylum application is being processed, more meaningful. Supported by funding from the County Administrative Boards, civil society organizations then in practice often provide Swedish language training, social 
information and social activities for asylum seekers in the local association sphere (Länsstyrelsen, 2017). Each person in the reference groups was asked about their contribution to the existential and normal everyday life of asylum seekers. The answers differed, of course, but a main difference was between actors working for public authorities and actors working for civil society organizations. Actors working for public authorities, such as social services, schools and the Migration Agency, had a mandate to receive asylum seekers and to give opportunities for a normal life by offering housing, basic economic assistance, and help with the procedures of the formalities of the asylum process (LMA card, address, filling in formulations, etc.). They stated that they did not really have a mandate to intervene in the existential quality of the refugees' lives. One social worker simply stated:

We should offer basic support according to legislation, but nothing more. Social life, integration and existential issues are things that the asylum seekers have to take care of themselves. We cannot do that.

Still, despite this narrow view of social work, the same person was very critical of the passivizing situation most asylum seekers ended up in. He discussed how it takes too long to get the decision about acceptance or rejection regarding the asylum application, and during that time many asylum seekers are broken down. I wonder, he said, "what would happen if we said: here is your permit, now you have three months to establish yourself. People would manage, I am sure of it. Instead they have to wait, and wait and wait.”

Professionals or volunteers working for civil society organizations answered differently. They saw it as their task to fulfill existential needs and create possibilities for normal social life. They also expressed criticism in line with the social worker above. Their main challenge was that they worked on a volunteer basis, had few resources and experienced difficulties in gaining access to the asylum seekers. One woman working locally for the Red Cross noted that it takes time to meet, talk and listen to people's existential problems, which is a demanding but extremely important task. Furthermore, she criticized the lack of information and communication from public authorities regarding the use of civil society organizations as a resource for meeting people's need for meaningful activities.

According to a priest from the Swedish Church, religious organizations naturally feel a responsibility to deal with people's existential needs. She expressed her view that is was healing to let people talk about their problems in front of a non-authority person, who does not share the same troublesome experiences, but who provides a sounding board for people's mental stress and worries. Her experience was also that the preconditions for taking care of people's existential needs at the Migration Agency's accommodations for asylum seekers were inadequate. The focus at these accommodations was instead, providing food and shelter.

In relation to the question put to participants in the reference groups about who is responsible for refugees' and migrants' existential needs, we have noticed a negotiation among the group participants as to whether this is actually an issue of significance. Actors in the reference groups working for public authorities such as the Migration Agency, the Public Employment Agency, the Police and social services said that these existential needs were not their professional responsibility. They took the stance that the individual refugee or migrant is more or less responsible for taking care of themselves in fulfilling these needs. One social worker's narrative quoted above, that 
social services should offer basic support according to legislation, nothing more, is one illustration of these standpoints. The caseworker from the Migration Agency argued in the same direction, "The individual has to search for different activities by him- or herself. To show curiosity and a will to do something with his/her life.” The same social worker quoted above declared, "we ought to put the largest responsibility where it belongs, on the individual, instead of giving state and municipal officials too much responsibility."

Most public actors felt that it was first and foremost the individual's responsibility to tackle any existential problems. They expressed a common feeling that public officials should treat all clients politely, objectively, and with the same kind of treatment and respect. However, in different ways they all expressed a lack of professional responsibility to involve themselves in people's existential worries or anxiety. Accordingly, these public officials claimed that their ability to involve themselves was restricted by the law (i. e., the migration law, the social services act, the regulation on labor market policy, etc.). The responsibility for engaging existential needs and problems was left to the individual refugee or migrant.

In contrast, the teachers working with introducing refugees and migrants into society as well as employees from civil society organizations such as the Swedish Church, the Red Cross and Fryshuset (the Freezer House) expressed a willingness to develop the existential support available to refugees and migrants. One male teacher working with social information courses at a local training center argued that by really seeing and listening to a person's life story, one becomes better prepared to understand and handle that person's feelings of misery and frustration. A Red Cross employee said that she meets people on a daily basis who are frustrated over their situation as asylum seekers, i.e., the new migration law preventing family reunion, the long waiting time, and being forced to live in uncertainty about whether they can stay in Sweden or will be deported. "We try to fulfill their existential needs, give support and we also work with different activities." One improvement of the reception which she desired was to introduce official information about the procedures in the asylum process and about residence permits as soon as people arrive in Sweden as asylum seekers. Such improvements could ease some of the stress and uncertainty of asylum seekers. She was critical of the fact that most official information is provided only after people have been given a residence permit and municipality placement.

In contrast to public actors, actors working for civil society organizations expressed a stronger willingness to engage themselves in people's existential needs and everyday social activities. Ironically, however, despite their willingness, their efforts are sometimes hampered by their organization's limited economic and staff resources or limited access to the target groups for which their social activities are intended. The limited access was the result of public regulations or weak multisectoral cooperation.

\section{Negotiated Stereotypes on Gender}

A second theme that became apparent in the analysis of the data was gender. In all groups and at every meeting the issue of "refugee and migrant women" was discussed. It is important to note that the notion of "refugee and migrant women" tend to be stereotyped and oversimplified in public debate and policymaking instead of recognizing the need for understanding migration as a gendered process involving different conditions for men and women in relation to other aspects, for instance 
education, class, and so on (Akman, 2014). In order to analyze how the perceived problem of "refugee and migrant women" was negotiated, we will proceed from a discussion in one of the reference groups where the challenges of women came up when the theme of integration was discussed.

A private entrepreneur running a refugee accommodation said that she had noted that the refugee women living at her place always stayed in their rooms. They did not take part in activities at the center and did not even go out to buy groceries. She declared that females in their culture (vaguely defined as Arabic) stick to themselves and their goal is to become housewives. Several of them have a high level of education, she stated, but still education is only a hobby, not a means to become a professional but a rather talented housewife who is financially supported by her husband. The entrepreneur emphasized her experiences of cultural differences by adding a story about how men with migrant backgrounds "imported" a wife from their home country rather than marrying a Swede. She had witnessed this practice on several occasions and was disappointed about it. In her opinion these "marriage arrangements" were a loss for Swedish society; e.g., she could not imagine a better way to integrate than through mixed marriages. She added, "it is also a loss for these women, who often get extremely alienated when they arrive in Sweden."

The private entrepreneur touched upon two well-established ideas in many European countries about the "flaws" of arranged marriages among migrants and the "strength" of integration through marriage between natives and migrants. These ideas have influenced laws and regulations concerning international marriages in several European countries. The most prominent example is probably the Danish legislation from 2002 on family reunification. The legislation was introduced to stop arranged international marriages, primarily among Pakistani migrants in Denmark, but in fact had a greater effect on stopping native Danes’ international marriages (Rytter, 2013).

One of the other participants, an activist who arranged meetings for women with migration experiences, added to the discussion of the private entrepreneur with further common (although equally simplified) ideas about "refugee and migrant women." She stated that the combination of culture, patriarchal structures, and the Swedish reception of refugees and migrants was devastating for women. "Many women who have lived in Sweden for a long time are depressed, isolated and need medical treatment." She thought that the reception of migrants and refugees in Sweden took away all sense of self-responsibility and made people passive. She added, "if it is a recognized problem that asylum seekers [as a total] get passive and depressed, the situation is even worse among women." A third person then entered the conversation and declared that he found the previous statements about refugee and migrant women too generalized and stereotyped. The private entrepreneur immediately defended herself and received support from a representative of the Red Cross who said, "It is not so dramatic to talk about these things; we had the same situation in Sweden 100 years ago."

The other participants in the reference group then declared their ambivalence towards the description of the situation of migrant women on one hand and towards the stereotyped image of "refugee and migrant women" on the other hand. They agreed that it is dangerous to be too stereotyped and general in their descriptions. At the same time, they concluded that they should not overdramatize this problem since they all recognized the description of the situation of refugee and migrant women as accurate and problematic. 
In this reference group, as well as in the other groups, the perceived problem of "refugee and migrant women" was discussed from different perspectives. Firstly, the participants discussed gender in terms of culture. Several participants, as in the example above with the private entrepreneur, described the cultural differences they experienced in encounters with refugee and migrant men and women. An interesting finding, though, is that narratives about gender issues were almost the only topic that also led to cultural explanations for refugee and migrant behavior. The example above shows how the participants in the reference groups negotiated how to formulate the perceived problem of "refugee and migrant women" without being prejudiced. Some of them preferred to explain perceived differences in terms of culture. Others were more sensitive about the idea of culture. They balanced the conversations by interrupting those whom they found too stereotyped in their descriptions. In this way, several of the participants showed an awareness of the difficulties that are related to the concept of culture, for example the risk of culturalization, othering and essentialism (Eliassi, 2015; Gustafsson, 2015). In this sense they struggled with the dilemma of how to address perceived differences between themselves and the refugees and migrants that they meet in the reception.

Another example came up in relation to the courses on social information about Swedish society. These courses are offered to asylum seekers with a residence permit in Sweden and consist of at least 60 hours of information and education about Swedish society. The teacher of these courses, supported by a social worker working with families and children at a place called "Landningsbanan" ("the Landing Strip"), discussed the need to recognize differences in culture and fundamental values. The oppression of women or the value of equality between men and women were topics that were raised in the information courses. Both the teacher and the social worker in the group concluded that there is a huge need among refugees and migrants (course participants) to understand and reflect upon these topics, especially in their mother tongue. In that sense, they supported a gender- and diversity-sensitive approach in the reception of refugees and migrants. At the same time, their hope to understand cultural differences also reflected a more normative perspective. The aim of the information presented in the courses was to change the ideas among the refugees and migrants rather than creating dialogue and mutual understanding between different values.

This kind of normative perspective surfaced at almost all the meetings and in all of the reference groups. The perceived problem of women being too passive was mainly framed as a consequence of an oppressive (male) culture and the solution was that those women should be "forced" to take responsibility for their integration through education and finding a job. One of the social workers stated that the refugees and migrants must get to know that in Sweden "you have to work. Both partners in the family have to work in order to manage and support the family." Hence the demand to join labor market activities was also discussed in terms of gender equality.

In addition to this normative perspective on gender equality and the passion for work activation, the perceived problem of women and their situation was also discussed from a more existential perspective. In the reference-group discussion summarized above, the activist described how the existential situation is difficult for all refugees and migrants, but was worse for women than for men. She then touched upon the problem that in the daily debate in the media, politicians, professionals, and others tend to talk about asylum seekers as one homogeneous category without recognizing gender and diversity. The solution to this existentially poor situation and environment from 
the perspective of the activist was the same as the one formulated above: to take part in education and work would lead to independence, self-responsibility and gender equality. But in order to do that, gender differences would have to be recognized in the reception structure.

This led to another aspect of the way the idea of a gender- and diversity-sensitive reception was discussed. Again, the teacher of the social information courses provided an example. He told the other participants about how he came to Sweden from Syria four years ago and received a residence permit within a few months. He began his university studies and has since finished a master's degree. At the time of the meeting, he was a full-time employee at the training center and he declared that:

I see myself in the line. I am not the one sitting behind the desk. I understand when someone comes forward and is angry, frustrated, and yells at me. When I came to Sweden, I knew English, so I could manage quite well. But imagine a 55-year-old Somali woman who only speaks (but does not read) Somali. It is not easy to learn Swedish and to understand a new language. People must have more patience. [...] I was privileged and came from a well-educated family. And no, a 55-year-old Somali woman cannot manage as well as I could. The problem is that the system does not understand this. The system treats everybody the same and with the same expectations.

In his narrative, reception work does not meet the needs of individuals and he reiterated the earlier idea that reception measures proceed from the needs of the host society, rather than the perspective of the migrant, leaving the latter in an ambivalent position of being both empowered and powerless (Andersson, 2014; Gibney, 2015; Gustafsson et al., 2012; Larsen, 2011). The teacher also presented another perspective on the perceived problem of "migrant women." His suggestion was that instead of viewing the 55-year-old Somali woman (or any migrant woman) as a problem, Swedish authorities must investigate problems inherent in their own systems and practices. He then argued in line with the aforementioned critique of minority model thinking as presented in research literature.

We identified a consensus in the reference groups' discussions concerning views about the problem of "refugee and migrant women." The main perceived problem was that they lived in culturally different contexts that expected them to stay at home and not pursue education or work. This, in turn, undermined the virtue of gender equality that was embraced among the participants, and was considered as a non-negotiable value in Swedish society and by Swedish authorities. This theme of negotiated stereotypes on gender is reflected in previous research and government inquiries where Swedish welfare benefits, such as paid parental leave, seem to cement migrant women's marginalization (Länsstyrelsen, 2017; SOU 2006:37; SOU 2012:9). Larsen explored how the Scandinavian welfare state intervenes in family lives in order to create "good citizens," sharing "Danish" values of gender equality and emancipation (Larsen, 2011). However, the strong focus on labor market activation and education in integration policies ignores the experiences of the women themselves as mothers and family members.

In contrast to these officially-sanctioned values of gender equality and labor market activation policies, a more critical discussion came up in the reference groups as they talked about the need to recognize cultural differences. Thus, according to the participants in the reference groups, reception in contemporary Sweden is not gender- 
and diversity-sensitive. The current reception approach is not able to solve differences between men and women, nor between individual circumstances. Participants expressed a willingness to do more in this area. On the one hand, those active in reception work desire to uphold the normative idea of gender equality, promote labor market activation, and change the way they perceive that many refugee and migrant women live their lives. On the other hand, there is a willingness to be more openminded, to find ways to talk about cultural differences in various languages, and to find ways to meet the individual needs of particular women or men instead of offering standardized support that is more in line with the officially proclaimed needs of society.

\section{Ambivalences Towards Various Refugee Groups}

The third theme encompasses the dilemma of receiving different categories of refugees and migrants and the present changes in the migration policies in Sweden. We will start out with a narrative which frames both of these dilemmas and how they intersect. At the first meeting, a police officer in one of the reference groups described his experiences of receiving refugees in a huge parking lot outside a shopping mall situated close to the Danish/Swedish border in November 2015.

There were hundreds of people waiting from all over the world. Buses came to pick them up and take them to municipalities all around Sweden that had prepared housing for them. Before they entered the buses, the caseworkers from the Migration Agency registered their names and nationality. Our job as police officers was to check that no person entered a bus without being registered. The first evening, the lights went out when the shopping mall closed. It was completely dark and I noted that many people never came forward and registered. We had absolutely no idea of who they were or where they went. It was completely out of control and people were desperate. [...] I think we have to pay a high price for this today, both in relation to those who we received and are now waiting for residence permit, and those who were never registered at all. From my perspective, of course, Sweden should receive refugees, those who come from war zones in Syria. But we also received all other kinds of migrants and travelers, and many of them entered Sweden without permission and were never registered.

In this narrative, the police officer frames the complex of different laws and values, and how human rights are challenged by the need for national security (Gibney, 2004). This negotiation has an effect on his everyday professional work, perhaps even more than the other participants in the reference groups, since his function as a police officer is to uphold the law, maintain order, and assure the security of the nation and its citizens. His views on whether Sweden should receive all kinds of people, categorized as "refugees from war zones" in contrast to "all kinds of other migrants and travelers," could be interpreted as representing a welfare-nationalistic position. This position stresses the importance of regulating the influx of refugees and migrants due to a fear of losing control of the national welfare state's resources, capabilities and its task to secure the order and well-being of its citizens (Gibney, 2004; Johansson, 2005; Johansson, 2008).

The narrative also opens up for negotiation over who is a worthy receiver. The police officer suggests that not everybody who arrived at the parking lot was worthy of reception in Sweden. His suggestions frame a current feature in studies about refugees 
and migrants, namely, the dilemma of who is a true refugee and who is not. Gibney (2004) describes how the UN Refugee Convention, in combination with the national migration law, regulates the categorization of migrants and divides them into three main categories: asylum seekers, economic migrants, and family migrants. All three categories have different legally legitimate claims for entry into Sweden based on the reason for the migration. A legitimate claim for a refugee and an asylum seeker would be, "Grant me asylum for, if you do not, I will be persecuted or face life-threatening danger" while an economic migrant would claim "Take me, or I and my family shall be condemned to a life of great poverty" (Gibney, 2004, pp. 9-12). In his analysis, Gibney (2004) denies that states have a responsibility for economic migrants. The sociologist Sassen (2016), in contrast, concludes that most refugees of today have "economic claims" and she describes how they are victims of a complex mix of conditions, wars, dead land and expulsions. Her main point is that liberal democracies all over the world have to recognize these refugees and include their claims for asylum among other legitimate claims (Sassen, 2016). When it comes to family migrants, Gibney refers to a double claim. On one hand, the claim is universal, "Take me in because families should be together" and on the other hand particular, "You owe it to me as a citizen to allow my cousin, daughter or spouse to enter" (Gibney, 2004, p. 14). The legitimacy of the claims for asylum is not only crucial for receiving a positive decision about asylum, but also for subsequent reception measures, residency status, and the possibilities for a future residence permit, citizenship, and family reunification (Hedlund, 2016).

The ambivalence among the professionals and volunteers in the reference groups about the assessment of who is a true refugee and who is not led to negotiations about the Swedish society's ability and willingness to receive refugees and migrants and to provide a worthy reception. The changes in Swedish migration policies were also discussed and negotiated. For example, the social worker at the Landing Strip stated, "We have a fantastic and generous reception, but we cannot receive everybody." In contrast, a teacher at the social information courses declared:

To me, the restrictive legislation breaks my heart. I'd rather have a crisis situation and work hard under stress and receive everybody than close the borders and have this restrictive legislation.

The social worker defended the changes in the migration policies while the teacher was critical. In another reference group, the participants shared their perspective on how the changes in legislation in 2016 had a direct impact on their work. An employee at the Red Cross described how friends had quit their jobs at the Migration Agency. They could not stand the changes in the legislation with temporary permits. They felt that human rights were set aside in favor of the security of the nation in a way that did not fit with their values and ethics. She also noticed that there was much less interest among people in general in offering their support or working as volunteers than a year ago. A public service officer at the Public Employment Agency explained:

The changes in the law in 2016 have led to changes in the openness among people and those who work with reception. In 2015 the politicians said that "we should open our hearts" and "Wir schaffen das" about the refugees crisis. In 2016 they said the opposite, and the crisis became the crisis of Swedish [and European] welfare institutions and welfare officers instead of a crisis for refugees and migrants. The government wanted to send a signal 
internationally and to countries that produce refugees and migrants, telling them that they are not welcome to Sweden. Instead, they have sent an internal signal to the nation of Sweden. I believe that the changes in legislation have had more impact on our willingness to receive refugees and migrants than on the willingness of refugees and migrants to come to Sweden. Now, we are used to not wanting to receive refugees and migrants.

He gives an example from his own work. He is supposed to create a resettlement plan for those who have received a permit to stay. But since it is a temporary residence permit it is almost impossible to create such a plan. At the same time, to find a job and prove that you can support yourself is vital to obtaining a permanent permit.

The participants in the reference groups working for the Swedish Church and the Red Cross explained that they met more and more desperate former and denied asylum seekers who did not know how to survive. The priest from the Swedish church explained that they took care of and supported these people, or if we use the vocabulary above, these "false" refugees. She did not want to provide details about this support in the reference group since representatives from both the Migration Agency and social services were present. A problem she had encountered and wanted to discuss, though, was that various groups were placed in opposition to each other. She and her colleagues as well as the volunteers from the Red Cross had received much criticism from the surrounding society because of their support for denied asylum seekers. In the critique, various vulnerable groups were juxtaposed. A common idea was, for example, that homeless people and people suffering from mental illness were suffering more now when asylum seekers took most or all of the available resources. The priest concluded that the juxtaposition of disadvantaged groups exposed them to hate and feelings of xenophobia or racism that were difficult to handle.

One of the social workers added that he had met the same kind of argumentation among his colleagues at the social services. They had their own idea of a hierarchy of who was the most vulnerable and who was most in need. He argued that in this evaluation, it was too easy to rely on the idea discussed above, about "true" and "false" refugees and migrants. In short, volunteers and professionals could justify a less ambitious treatment of some groups with the argument that many among the group of refugees and migrants were not worthy of support and social services since they were not "true" refugees. In this way, the insiders and the outsiders of a worthy reception were defined, negotiated and discussed in the different reference groups.

\section{Conclusions}

Initially, we framed the reference groups as cultural encounters between representatives of different knowledge-producing groups working under different jurisdictions and conditions. In addition, by referring to the concept of concurrences, our ambition was to emphasize different voices and claims and how they were performed or narrated in relation to and in negotiation with each other. Negotiation became possible within the framework of the research design during the reference group meetings. The design with mixed reference groups made it possible to frame the reception of refugees and migrants as a joint responsibility with shared problems and challenges.

This kind of conversation and exchange of experiences is not taking place in the receiving actors' everyday work within the reception structure. As outlined above, the 
Swedish reception of refugees and migrants is not a "system" governed by one general law or regulation, but a complex "reception structure" consisting of different sectors and agencies that act independently of each other and rarely collaborate. They all have an impact on the refugees' and migrants' lives, but how they operate and intersect, as well as the joint outcome of their work, is difficult to understand if their agency and professional practices are not analyzed together (Andersson, 2014; Gustafsson, 2015; Zetterqvist Nelson \& Hagström, 2016).

The refugee situation in 2015 temporarily changed the "structure" of reception and for a few months during the autumn, collaboration became necessary in order to solve the emergent situation. The receiving actors participating in our reference group meetings told of their personal experiences from both the fall of 2015 and the impact of the subsequent restrictive policy changes in 2016. Different events and procedures were highlighted as examples of how the challenging situation in the fall of 2015 required multisectoral cooperation and new, flexible solutions. One female social worker said with reference to a representative from the Red Cross: "You did a fantastic job. But even different municipal administrations did a fantastic job. Everyone took part and adjusted. Everyone came together."

One benefit of this research approach is that we can reach a comprehensive narrative of the reception of refugees and migrants in contemporary Sweden, but also highlight issues and challenges that the representatives of different knowledgeproducing groups have in common - problems that could be better addressed through cooperation. This does not mean that different actors have the same relation to or solution to these issues. We have, for example, analyzed the difference between the ability and willingness to deal with existential needs, gender and diversity and ambivalences towards what are perceived as "true" and "false" refugees and towards changes in migration policy. The most obvious, but perhaps unsurprising, differences could be seen between those who work for public authorities and those who work for civil society organizations. The former are limited by the ability of their authorities which are regulated and financed in relation to specific mandates and assignments. The latter can work more in accordance with willingness but are limited by their ability in terms of time and resources.

In relation to the first theme, we found that no matter which organization they belonged to, reference group participants agreed on the problem of overlooking refugees' and migrants' existential needs. Those working for public authorities believed that it was not their problem to deal with. They claimed that it was foremost an individual responsibility for the refugee or migrant. Those working for civil society organizations were prepared to take on larger responsibility and to act as sounding boards for fellow humans. While the analysis showed that the actors taking part in the reception structure became aware of overlooked existential needs, who is best equipped to address the unmet needs has not yet been resolved. Reception work actors are confronted with the risk that if overlooked needs are not dealt with anywhere in the reception structure, it could lead to severe consequences for the physical and mental health of refugees and migrants, which also has consequences for their long-term resettlement in the new country (Valenta \& Berg, 2010). For these reasons, the responsibility for taking care of existential needs must be communicated and undertaken by the receiving actors in a collaborative dialogue with each other and with refugee and migrant groups and individuals that require some kind of existential support (Beresford \& Croft, 2004). 
When it came to the second theme, negotiated stereotypes on gender, we saw in the analysis that all participants agreed upon the need for recognizing gender differences and especially the situation for women who migrate. There were, however, differences in how the "problem" was perceived and formulated. Those working for public authorities focused on the normative perspective of promoting gender equality through education and working activation for women. Those working in civil society organizations and in close relation to refugees and migrants through their position as grass-root social workers and teachers had a larger engagement in finding ways to promote mutual understanding of cultural differences. They also recognized the need for a gender- and diversity-sensitive reception. One lesson that can be learned is how the reference groups negotiate and formulate the problem of gender and diversity and how to avoid using a stereotypical and othering discourse.

In the third theme about ambivalences towards who are perceived as "worthy", "true" and "false" refugees, the main difference was that civil society organizations helped everyone who came to them regardless of legal status, while public authorities were only allowed to support those who were still asylum seekers or had received a permit to stay. This third theme highlights the impact of legislation and the conditions for those who work and are involved in the reception structure. Migration policy limits a country's ability to receive refugees and migrants, but also affects the willingness among those actors who receive. In times of shifting migration policies, the issue of who is a worthy receiver is negotiated. Hence, an ethical dilemma that affects the everyday work of social workers and other welfare state professional groups was raised and contested in the reference groups. As stated by one participant, the legal changes in Sweden in 2016 towards a European minimum standard sent signals to refugees and migrants not to come to Sweden. He suggested that they also sent internal signals to actors in the reception structure that they should not welcome refugees and migrants. His statement created a dialogue in the reference group about the direct impact of law and regulation on the participants' daily work. The statement and the resulting dialogue demonstrates how the ability to receive refugees and migrants is intertwined or sometimes supported by the willingness of reception actors. This has an impact on how social work responds to the needs of refugees and migrants in different political climates. The division that emerged in the interviews, between who was defined as a "true" refugee and who was not, was shaped by the participants' different knowledgeproducing groups and different levels of authority. The division was supported by contemporary restrictive legislation that gives more authority to border controls, security issues, and police forces than to human rights and social work values (Jönsson \& Heggem Kojan, 2017; Lundqvist \& Mulinari, 2016). Such a focus on social control also affects contemporary debates about migration in Sweden and other European countries. An implication is that social workers need to be more actively involved in debates on migration so that the importance of responding to human suffering and inequality is not lost to the dominant perspective on control and security.

This conclusion about the dominance of control and security over human rights and social work values can also be situated in the wider context of contemporary Europe and Sweden's role in negotiating general standards for the asylum process and for receiving a "fair share" of refugees and migrants between countries in Europe (Gibney, 2015). The changes in Swedish migration policy sent signals to other European countries that a minimum standard was enough instead of higher demands on a "worthy reception.” Where this will end we do not know, but lessons are to be learned from 
listening to the different voices and claims among those involved in the reception structure.

\section{References}

Ahmadi, N. (1998/2003). Ungdom, kulturmöten och identitet. Stockholm. [Youth, cultural encounters and identity]. Liber och SiS.

Akman, H. (Ed.). (2014). Negotiating identity in Scandinavia: Women, migration, and the diaspora. New York: Berghahn Books.

Andersson, H. E., Ascher, H., Björnberg, U., \& Eastmond, M. (2010). Mellan det förflutna och framtiden: Asylsökande barns välfärd, hälsa och välbefinnande . [Between the past and the future: Asylum seeking children's welfare, health and well-being]. Göteborg: Centrum för Europaforskning.

Andersson, R. (2014). Illegality, inc.: Clandestine migration and the business of bordering Europe. Berkeley: University of California Press.

Beresford, P., \& Croft, S. (2004). Service users and practioners reunited: The key component for social work reform. British Journal of Social Work, 34(1), 53-64. doi: https://doi.org/10.1093/bjsw/bch005

Brekke, J. P (2004). While we are waiting: Uncertainty and empowerment among asylum- seekers in Sweden (Report No. 2004:10). Institute for Social Research. Oslo. Retrieved from https://brage.bibsys.no/xmlui/bitstream/handle/11250/2440626/R 2004 10.pdf?s equence $=3$

Brydon, D., Forsgren, P., \& Fur, G. (Eds). (2017). Concurrent imaginaries, postcolonial worlds. Towards revised histories. Amsterdam: Brill.

Bunar, N. (Ed.). (2015). Nyanlända och lärande - mottagande och inkludering [Newly arrived and education - reception and inclusion]. Stockholm: Natur \& Kultur.

Castles, S., \& Miller, M., J. (2011). The age of migration. International population movements in the modern world. Basingstoke: Palgrave.

Eliassi, B. (2015). Constructing cultural otherness within the Swedish welfare state: The case of social workers in Sweden. Qualitative Social Work, 14(4), 554-571. doi: https://doi.org/10.1177/1473325014559091.

Esping-Andersen, G. (1990).The three worlds of welfare capitalism. Cambridge: Polity Press.

Europeiska Unionen. (2010). Europeiska Rådet[The European Council] 2010/C $115 / 01$.

Europeiska Unionen. (2013). Mottagandedirektiv [The directive for reception] 2013/33/EU.

Fur, G. (2017). Concurrences as a methodology for discerning concurrent histories. In D. Brydon, P. Forsgren, \& G. Fur (Eds.), Concurrent imaginaries, postcolonial worlds: Towards revised histories (pp. 3358). Amsterdam: Brill. doi: https://doi.org/10.1163/9789004347601_003 
Gibney, M. J. (2004). The ethics and politics of asylum: Liberal democracy and the response to refugees. Cambridge: Cambridge University Press. doi: https://doi.org/10.1017/CBO9780511490248.

Gibney, M. J. (2015). Refugees and justice between the states. European Journal of Political Theory, 14(4), 448-463. doi: https://doi.org/10.1177/1474885115585325

Gustafsson, K. (2015). The reception of separated minors in Sweden: To receive with grace and knowledge. In E. Heikkilä, A. Kostiainen, J. Leinonen, \& I. Söderling, I. (Eds.), Participation, integration and recognition: Changing pathways to immigrant incorporation (pp. 111-124). Turku: Institute of Migration.

Gustafsson, K., Fioretos, I., \& Norström, E. (2012). Between empowerment and powerlessness: Separated minors in Sweden. New Directions in Child and Adolescence Development, 2012(136), 65-77. doi: https://doi.org/10.1002/cad.20011

Hall, S. (1997). Representation: Cultural representations and signifying practices. London: Sage Publications.

Hastrup, K. (2010). Kultur. Den flexibla gemenskapen [Culture: The flexible community]. Lund: Studentlitteratur.

Hedlund, D. (2016). Drawing the limits: Unaccompanied minors in Swedish asylum policy and procedure. Stockholm: Stockholm University Department of Child and Youth Studies.

Hessle, S. (1988). Familjer i sönderfall: En rapport från samhällsvården [Families and disintegration: A report from the social services]. Göteborg: Norstedts.

International Federation of Social Workers [IFSW]. (2012/2004). Statement of ethical principles, International Federation of Social Workers. Retrieved from http://ifsw.org/policies/statement-of-ethical-principles/

Johansson, C. (2005). Välkomna till Sverige? Svenska migrationspolitiska diskurser under 1900-talets andra hälft [Welcome to Sweden? Swedish migration policy discourses during the second half of the 20th century]. Malmö: Bokbox förlag.

Johansson, J. (2008). ”Så gör vi inte här i Sverige. Vi brukar göra så här.” Retorik och praktik i LO:s invandrarpolitik 1945-1981 (Doctoral dissertation). [We do not do it like this in Sweden. We do like this: Rhetoric and practice in LO's immigration policy 1945-1981]. Växjö: Växjö University Press.

Jönsson, J. H., \& Heggem Kojan, B. (2017). Social justice beyond neoliberal welfare nationalism. Challenges of increased immigration to Sweden and Norway. Critical and Radical Social Work. An International Journal, 5(3), 301-317. doi: https://doi.org/10.1332/204986017X15029696492785

Larsen, B. R. (2011). Becoming part of welfare Scandinavia: Integration through the spatial dispersal of newly arrived refugees in Denmark. Journal of Ethnic and Migration Studies, 37(2), 333-350. doi: https://doi.org/10.1080/1369183X.2011.521337.

Lundqvist, Å., \& Mulinari, D. (2016). Introduktion [Introduction]. Socialvetenskaplig Tidskrift, 23(3-4), 187-191. 
Länsstyrelsen. (2017). Tidiga insatser för asylsökande [Early interventions for asylum seekers]. Retrieved from http://extra.lansstyrelsen.se/integration/Sv/tidigainsatser-asylsokande/Sidor/default.aspx

Migrationsverket. (2017). Översikter och statistik från tidigare år [Overview and time series]. Retrieved from https://www.migrationsverket.se/OmMigrationsverket/Statistik/Oversikter-och-statistik-fran-tidigare-ar.html

Montesino, N., \& Righard, E. (Eds). (2015). Socialt arbete och migration [Social work and migration]. Malmö: Gleerups.

Nilsson Folke, J. (2017). Lived transitions: Experiences of learning and inclusion among newly arrived students. Stockholms Universitet: Samhällsvetenskapliga fakulteten, Barn- och ungdomsvetenskapliga institutionen.

Ottosson, L., \& Lundberg, A. (2013). 'People out of place'? Advocates' negotiations on children's participation in the asylum application process in Sweden. International Journal of Law, Policy and the Family, 27(2), 266-287. doi: https://doi.org/10.1093/lawfam/ebt003

Pripp, O. (2005). Den segregerande välviljan: Kultur som makt [The segregating goodwill: Culture as power].. In: M. Öhlander (Ed.), Bruket av kultur: Hur kultur används och görs socialt verksamt (pp. 73-98). Lund: Studentlitteratur.

Regeringens skrivelse. (2016). Verksamheten i Europeiska unionen under 2016 [Operations in the European Union in 2016, Skr. 2016/17:115]. Retrieved from https://www.regeringen.se/494698/contentassets/fd2216a175884446b203965e1d d45afd/verksamheten-i-europeiska-unionen-under-2016-skr.-201617115

Rytter, M. (2013). Family upheaval: Generation, mobility and relatedness among Pakistani migrants in Denmark. Copenhagen: Berghahn Books.

Sainsbury, D. (2012). Welfare states and immigrant rights: The politics of inclusion and exclusion. Oxford: Oxford University Press. doi: https://doi.org/10.1093/acprof:oso/9780199654772.001.0001

Safipour, J., Hadziabdic E., Hultsjö, S., \& Bachrach-Lindström, M. (2017). Measuring nursing students' cultural awareness: A cross-sectional study among three universities in southern Sweden. Journal of Nursing Education and Practice, 7(1), 107-113. doi: https://doi.org/10.5430/jnep.v7n1p107.

Sassen, S. (2016). A massive loss of habitat: New drivers for migration. Sociology of Development, 2(2), 204-233. doi: https://doi.org/10.1525/sod.2016.2.2.204.

Schierenbeck, I. (2003). Bakom välfärdsstatens dörrar [Behind the welfare state's doors]. Umeå: Borea.

SFS 1994:137. Lag om mottagande av asylsökande m.fl [Act on reception of asylum seekers et al.].

SFS 2001:453 Socialtjänstlagen [Act on social services].

SFS 2010:197. Lag om etableringsinsatser för vissa nyanlända invandrare [Act on resettlement activities for some newly arrived immigrants].

SFS 2016:38. Lag om mottagande av vissa nyanlända invandrare för bosättning [Act on reception of some newly arrived immigrants for residence]. 
SFS 2016:752. Lag om tillfälliga begränsningar av möjligheten att få uppehållstillstånd i Sverige [Act on temporary restrictions on the possibility of obtaining a residence permit in Sweden].

SOU 2006:37. Om välfärdens gränser och det villkorade medborgarskapet. [On the limits of the welfare and conditional citizenship]. Stockholm: Fritzes offentliga publikationer.

SOU 2012:9. Förmån eller fälla: Nyanländas uttag av föräldrapenning. [Benefit or Failure: Newly arriver's withdrawal of parental allowance]. Stockholm: Fritzes offentliga publikationer.

SOU 2017:12. Att ta emot människor på flykt. Sverige hösten 2015 [To receive people on flight. Sweden autumn 2015]. Stockholm: Fritzes offentliga publikationer.

Soydan, H. (1995). Försäkringskassan och invandrarna [The social insurance agency and immigrants]. Malmö: Bokbox Förlag.

Svensson, M. (2013). Betwixt and between: Hope and the meaning of school for asylum-seeking children in Sweden. Nordic Journal of Migration Research, 3(3), 162-170. doi: https://doi.org/10.2478/njmr-2013-0007.

Svensson, M. (2017). Hoppet om en framtidsplats. Asylsökande barn i den svenska skolan_[Hoping for a future home. Asylum-seeking children attending Swedish school, no. 402]. Göteborg: Gothenburg Studies in Educational Sciences.

Turunen, J., \& Weinryb, N. (2017). Volontärer i välfärdsstaten - socialt arbete med transitflyktingar som politisk handling [Volunteers in the welfare state - Social work with trans-refugees as political action]. In S. Linde \& R. Scaramuzzino (Eds.), Socialt arbete i civilsamhället - Aktörer, former och funktioner [Social work in civil society: Actors, shapes and functions] (pp. 175-200). Lund: Studentlitteratur.

Valenta, M., \& Berg, B. (2010). User involvement and empowerment among asylum seekers in Norwegian reception centres. European Journal of Social Work, 13(4), 483-501. doi: https://doi.org/10.1080/13691451003603406

Zetterqvist Nelson, K., \& Hagström, M. (2016). Nyanlända barn och den svenska mottagningsstrukturen. Röster om hösten 2015 och en kunskapsöversikt [New arrivals and Swedish reception structure. Voices on autumn 2015 and a research overview]. Stockholm: FORTE (Forskningsrådet för hälsa, arbetsliv och välfärd).

Author note: Kristina Gustafsson, PhD, Department of Social Work, Linnaeus University, 35195 Växjö, Sweden. kristina.gustafsson@lnu.se. Jesper Johansson PhD, Department of Social Work, Linnaeus University 35195 Växjö. Sweden. jesper.johansson@lnu.se 